\title{
The Effects of Different Feeding Rates on Growth Performance and Stomach Volume in Rainbow Trout (Oncorhynchus mykiss)
}

\author{
H. A. Karabulut ${ }^{1}$, B. Senoglu ${ }^{1} \&$ I. Z. Kurtoglu ${ }^{1}$ \\ ${ }^{1}$ Department of Aquaculture, Faculty of Fisheries, Recep Tayyip Erdogan University, Rize, Turkey \\ Correspondence: H. A. Karabulut, Department of Aquaculture, Faculty of Fisheries, Recep Tayyip Erdogan \\ University, Rize 53100, Turkey. E-mail: huriye.ariman@erdogan.edu.tr
}

Received: April 8, 2018

doi:10.5539/jas.v10n7p19
Accepted: May 7, $2018 \quad$ Online Published: June 15, 2018

URL: https://doi.org/10.5539/jas.v10n7p19

The research is financed by Recep Tayyip Erdogan University Scientific Research Projects Unit. Project No. 2012.103.02.1.

\begin{abstract}
In this study, the effects of various daily feeding ratios on the growth, stomach volume and meat composition in rainbow trout (Oncorhynchus mykiss) were investigated. The feeding experiment was conducted in $450 \mathrm{~L}$ volume fiberglass tanks with $3 \times 3$ factorial patterns. During the experiment, while food were given to the fish at the first group in the $0.5 \%$ (I) of ratio of their live weight, the second group at the level of $2 \%$ (II) food were given to the fish, at the third group at the level of $6 \%$ (III) food. The initial weight and size values of the groups were $76.16 \pm 0.41 \mathrm{~g}$ and $19.11 \pm 1.63 \mathrm{~cm}$, respectively. The final weight and size values reached up to $128.89 \pm 34.21 \mathrm{~g}, 25.09 \pm 2.37 \mathrm{~cm} ; 236.05 \pm 89.32 \mathrm{~g}, 24.78 \pm 2.22 \mathrm{~cm}$; and $238.91 \pm 86.67 \mathrm{~g}, 21.65 \pm 1.64 \mathrm{~cm}$, for groups I, II, and III respectively. The best growth performance in terms of weight was obtained in group III, while the best growth performance in terms of size was obtained in groups I and II $(\mathrm{P}<0.05)$. The best feed conversion ratio was determined in the low feeding group I $(\mathrm{P}<0.05)$. At the end of experiment, three of the experimental groups were different from each other. The highest stomach volume was measured in group III ( $\mathrm{P}<$ 0.05 ). In conclusion, the $6 \%$ feeding ratio increased the growth and significantly increased the stomach volume, however decreased the feed conversion ratio.
\end{abstract}

Keywords: rainbow trout, feeding ratio, growth, meat composition

\section{Introduction}

Feeding expenses in sea and freshwater rainbow trout (Oncorhynchus mykiss) aquaculture comprise $60-70 \%$ of the total costs of consumables in the business. This clearly exhibits the importance of feed and feeding in the aquaculture business (Bureau et al., 2006; Bascinar et al., 2008; Korkut, 2013; Karabulut et al., 2017). To decrease feeding expenses, it is necessary to determine the most suitable feeding strategies and to establish effective feeding protocols. Therefore studies on fish feeding have focused on both feed intake of the fish and fish growth. Recently, many studies have been conducted on feeding ratios, feeding frequency and compensatory growth (Kuyumcu, 2001; López et al., 2002; Keskin \& Erdem, 2005; Bureau et al., 2006; Bascinar et al., 2008; Marimuthu et al., 2011; Guzel \& Arvas, 2011; Al Zahrani et al., 2013; Abidi \& Khan, 2014). Increased fish production can be accomplished by knowing the feeding characteristics of the fish that will be cultured and the digestion of the feed that the fish ingest (Horn, 1998; Ozdemir et al., 2002).

In some aquaculture studies on feeding and digestion, stomach volume evaluations revealed experimental information that the increased amount of feed increased the stomach volume. However, this evidence was not sufficient to measure the stomach volume (Pirhonen \& Farsman, 1998; Ogata \& Shearer, 2000; Karatas, 2005). This information on stomach volume can help to explain the differences in feed intake and feed digestibility between individuals. The measurement of stomach volume in rainbow trout fish is carried out with high accuracy by killing the fish right after the feed ingestion and removing the stomach (Jobling et al., 2001). Nevertheless, stomach volume can be measured when the stomach of the fish is full, contains semi-digested food, or even is empty. In these cases, the measurements can be carried out by emptying the stomach of contents and determining the weight of the ingested feed or by injecting a material of measured volume into the stomach (Jobling et al., 
2001; Karatas, 2005). The favored material for these measurements is mercury, because it is the only metal that takes the shape of the volume in which it is placed and is in liquid form at room temperature. Its high density facilitates volume estimation by weighing (Karabulut \& Yandi, 2011).

This study aimed to examine the interactions between different feeding ratios, stomach volume and the differences in growth performances in rainbow trout.

\section{Materials and Method}

\subsection{Fish, Experimental Design and Conditions}

The study was conducted at Recep Tayyip Erdogan University Fisheries Research Center. Two hundred seventy rainbow trout fish produced in the center, with an average weight of $76.16 \pm 0.41 \mathrm{~g}$, an average size of $19.11 \pm 1.63$ $\mathrm{cm}$, were placed in nine $(1.1 \times 1.1 \times 0.6 \mathrm{~m}, 450 \mathrm{~L})$ fiberglass tanks filled with $400 \mathrm{~L}$ of water. The tanks were maintained under natural photoperiod regime (average 16L/8D hours). The study was conducted for 4 months. To determine periodical fish development during the experiment, individual fish weights were measured with a digital scale with $\pm 0.1 \mathrm{~g}$ sensitivity, and their sizes were measured using a Von Bayer method (Pieper et al., 1983) trough with $\pm 1 \mathrm{~mm}$ sensitivity. Anesthesia, $35 \mathrm{mg} \mathrm{L}^{-1}$ benzocaine, was applied in periodic measurements. In the feeding of the groups during the research, extruded commercial rainbow trout feed numbers $3 \mathrm{~mm}$ (crude protein $44 \%$, crude lipid $20 \%$, digestible energy $4000 \mathrm{kcal} / \mathrm{kg}$ ) and $4 \mathrm{~mm}$ (crude protein $42 \%$, crude lipid $21 \%$, digestible energy $4300 \mathrm{kcal} / \mathrm{kg}$ ) were used. The groups were fed at $0.5 \%$ (Group I), $2 \%$ (Group II), or $6 \%$ (Group III) of their body weights in 3 three times in a day (at 09:00, 13:00, and 17:00). The amounts of feed given to the groups were calculated on the basis of the 15 day increases biomass values.

\subsection{Determination of the Stomach Volume}

At the end of the study, 12 fish, randomly taken from each tank, were anesthetized with a deep anesthesia (50 $\mathrm{ppm}$ ). The digestive systems of the fish were removed, starting from the gills and including esophagus, stomach, and pyloric pouch, with no damage. The mercury injection procedure into the emptied stomach was carried out quickly so that the mercury would not pass out of the stomach, and the amount of mercury that the stomach could take was recorded as the volume of the stomach (Figure 1).
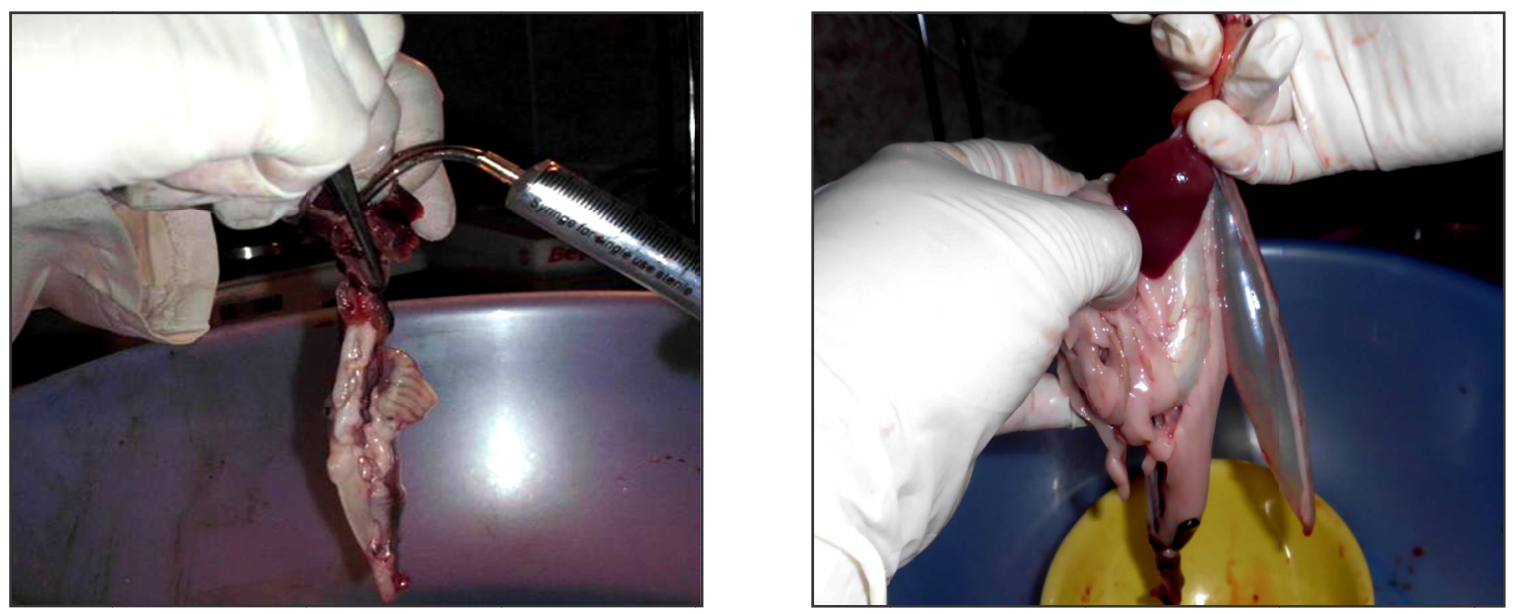

Figure 1. Injecting of the mercury into stomach

Mercury used in the stomach volume measurement was accumulated in the reservoir and reused. Tissue samples, gloves, masks, napkins, and other materials that had been in contact with mercury were controllably deposited and disposed of in accordance with procedures explained in the Regulation on Control of Hazardous Wastes.

\subsection{Analysis}

Samples of fishes were analyzed in replicates, using standard methods (AOAC, 2000). Crude protein content $(\mathrm{N} \times 6.25)$ was determined by Kjeldahl method after acid digestion using Automatic Kjeldahl System Crude lipid content was determined using a solvent extractor Velp SER 148/6 (Velp Scientifica, Milano, Italy) with petroleum ether $\left(130^{\circ} \mathrm{C}\right)$. Dry matter content was determined by oven dried at $105{ }^{\circ} \mathrm{C}$ to constant weight. Crude 
ash content was determined by incineration in a muffle furnace $\left(550{ }^{\circ} \mathrm{C}\right.$ for $\left.12 \mathrm{~h}\right)$. To determine the stomach volume and growth performance of the fish taken randomly from each tank, meat composition analyses were conducted. Results are shown as the standard deviation of the mean. SPSS 22.0 package program was used to evaluate the findings of the present study. Differences between groups were determined by ANOVA test. When the difference was statistically significant, the Duncan multiple comparison test was used to determine the difference between the groups.

\section{Results and Discussion}

This study aimed to evaluate the differences seen in the stomach volume in rainbow trout fish as a result of different feeding densities. The average water temperature during the study was $10.50 \pm 0.91{ }^{\circ} \mathrm{C}\left(\min .8{ }^{\circ} \mathrm{C}-\mathrm{max}\right.$. $13^{\circ} \mathrm{C}$ ), pH was $7.60 \pm 0.52$ and oxygen level was $8.57 \pm 0.77 \mathrm{mg} \mathrm{L}^{-1}$.

No rainbow trout fish died during the study.

\subsection{Growth Performance}

The obtained growth and stomach volume parameters are shown in Table 1.

Table 1. Parameters of growth and stomach volume $(\bar{X} \pm \mathrm{SH})$

\begin{tabular}{llll}
\hline & \multicolumn{3}{c}{ Experimental groups } \\
\cline { 2 - 4 } & I $(0.5 \%)$ & II $(2 \%)$ & III $(6 \%)$ \\
\hline $\mathrm{W}_{\mathrm{i}}(\mathrm{g}) *$ & $76.60 \pm 0.45$ & $76.25 \pm 0.43$ & $75.65 \pm 0.39$ \\
$\mathrm{~L}_{\mathrm{i}}(\mathrm{cm})$ & $19.75 \pm 1.68$ & $19.40 \pm 1.81$ & $18.35 \pm 1.03$ \\
$\mathrm{~W}_{\mathrm{f}}(\mathrm{g}) * *$ & $236.05 \pm 89.32^{\mathrm{b}}$ & $238.91 \pm 86.67^{\mathrm{b}}$ \\
$\mathrm{L}_{\mathrm{f}}(\mathrm{cm})$ & $128.86 \pm 34.21^{\mathrm{a}}$ & $24.78 \pm 2.22^{\mathrm{a}}$ & $21.65 \pm 1.64^{\mathrm{b}}$ \\
${ }^{1} \mathrm{WG}(\%)$ & $25.09 \pm 2.37^{\mathrm{a}}$ & $209.46 \pm 45.61^{\mathrm{b}}$ & $214.93 \pm 42.11^{\mathrm{c}}$ \\
${ }^{2} \mathrm{SGR}(\%)$ & $68.18 \pm 16.32^{\mathrm{a}}$ & $1.43 \pm 0.68^{\mathrm{b}}$ & $1.44 \pm 0.79^{\mathrm{b}}$ \\
${ }^{3} \mathrm{FCR}$ & $0.69 \pm 0.38^{\mathrm{a}}$ & $1.59 \pm 0.82^{\mathrm{b}}$ & $3.17 \pm 1.49^{\mathrm{c}}$ \\
${ }^{4} \mathrm{CF}(\%)$ & $0.80 \pm 0.35^{\mathrm{a}}$ & $1.43 \pm 0.06^{\mathrm{b}}$ & $1.45 \pm 0.03^{\mathrm{b}}$ \\
${ }^{5} \mathrm{HSI}(\%)$ & $1.24 \pm 0.06^{\mathrm{a}}$ & $1.12 \pm 0.16^{\mathrm{a}}$ & $1.22 \pm 0.16^{\mathrm{b}}$ \\
${ }^{6}$ VSI (\%) & $1.12 \pm 0.21^{\mathrm{a}}$ & $12.81 \pm 1.67^{\mathrm{bc}}$ & $13.65 \pm 1.13^{\mathrm{c}}$ \\
Stomach Volume (mL) & $10.42 \pm 2.12^{\mathrm{a}}$ & $14.61 \pm 3.74^{\mathrm{b}}$ & $16.01 \pm 0.64^{\mathrm{c}}$ \\
\hline
\end{tabular}

Note. Values in the same row with no common superscripts are significantly different $(\mathrm{P}<0.05)$. *: Initial mean weights, and **: Final mean weights.

${ }^{1}$ WGR (Weight gain rate, $\left.\%\right)=100 \times\left(\mathrm{W}_{\mathrm{f}}-\mathrm{W}_{\mathrm{i}}\right) / \mathrm{W}_{\mathrm{i}}$ (Segato et al., 2006);

${ }^{2}$ SGR (Specific growth rate, $\%$ day $\left.^{-1}\right)=\left[\ln \left(\mathrm{W}_{\mathrm{f}}-\ln \mathrm{W}_{\mathrm{i}}\right)\right] /$ days $\times 100$ (Morales et al., 1994);

${ }^{3}$ FCR $($ Feed conversion ratio) $=$ Dry feed intake (g)/Weight gain (g) (Morales et al., 1994);

${ }^{4} \mathrm{CF}$ (Condition factor, \%) $=\left(\mathrm{W} / \mathrm{L}^{3}\right) \times 100$;

${ }^{5}$ HSI (Hepatosomatic index, $\left.\%\right)=100 \times$ Liver weight/Body weigh (Segato et al., 2006);

${ }^{6}$ VSI (Viscerosomatic index, \%) $=100 \times$ Viscera weight/Body weight (Segato et al., 2006).

At the end of the experiment final average weights of groups were detected as $128.86 \pm 34.21 \mathrm{~g}(0.5 \%)$, $236.05 \pm 89.32 \mathrm{~g}(2 \%)$ and $238.91 \pm 86.67 \mathrm{~g} \mathrm{(6 \% ),} \mathrm{respectively.} \mathrm{Tarim} \mathrm{and} \mathrm{Akyurt} \mathrm{(1992),} \mathrm{in} \mathrm{their} \mathrm{study} \mathrm{on}$ different feeding applications on brood rainbow trout, found that the highest average weight gain was determined to be in the $1.5 \%$ feeding group, whereas the lowest was determined in the $0.5 \%$ feeding group. According to Ustaoglu and Bircan (1998), Kuyumcu (2001), and Keskin and Erdem (2005), the highest weight gain in different feeding applications on rainbow trout was determined to be in the groups in which the fish were fed to satiation. Also, it was concluded that instead of high-ratio feeding, the fish should be fed in accordance with their needs. That result was in accordance with the results of the present study regarding the weight gain as a result of the $6 \%$ feeding ratio. In the evaluation values calculated at the end of the study, the best result was obtained in the $2 \%$ feeding group, group II, with 1.59 ; this was followed by the $0.5 \%$ feeding group, group I, with 0.80 and the $6 \%$ feeding group, group III, with 3.17. The data on feed conversion showed that the results were better than those obtained by Storebakken et al. (1981), Tarim and Akyurt (1992), Sahin (1994), Ustaoglu and Bircan (1998), 
Kuyumcu (2001), and Keskin and Erdem (2005), and the results obtained by Bureau et al. (2006) were similar to those obtained in Group I of the present study.

During the trial, the differences in the average weight gain, specific growth rate, and condition factor values between group I and group II and between group I and group III were statistically significant $(\mathrm{P}<0.05)$, whereas the differences between group II and group III were statistically not significant.

Examining the feed conversion ratio analysis results, the differences between groups I, II and III were statistically significant $(\mathrm{P}<0.05)$. In rainbow trout feeding, growth occurs when the feed conversion ratio is above a certain value; however, feed cost increases in such cases. The recommended feed consumption is the value wherein the feed conversion ratio is minimum; nonetheless, growth rate increases when feed consumption increases (De Silva \& Anderson, 1995). In the present study, as the feed application was excessive in group III, the growth rate increased, but the feed conversion ratio also increased. At the end of the experiment, by making use the dissections results on fish hepatosomatic indices and viscerosomatic indices of fish have been determined. According to the results of the analysis on the characteristics of meat composition, hepatosomatic indices was found statistically insignificant, while viscerosomatic indices were statistically significant $(p<0.05)$. At the end of the study, upon examination of the results obtained from dissections, viscerosomatic index values were parallel to those obtained by Ustaoglu (1996) and higher than those obtained by Guzel and Arvas (2011). Hepatosomatic index values were lower than those reported by Ustaoglu (1996) and Keskin and Erdem (2005) and similar to those obtained by Guzel and Arvas (2011).

\subsection{Stomach Volume}

At the end of the study, the fish were dissected for stomach volume measurements, stomach contents were emptied, and the stomachs were filled with mercury. Stomach volume was found to be $7.72 \pm 2.16 \mathrm{~mL}$ in group I, while stomach volume values were $14.61 \pm 3.74 \mathrm{~mL}$ and $16.01 \pm 5.64 \mathrm{~mL}$ in group II and group III, respectively. According to the statistical analysis results; the difference between groups I - II and I - III were significant ( $\mathrm{P}<$ $0.05)$, while that between groups II - III was not significant $(\mathrm{P}>0.05)$. At the end of the study, stomach volume was found to be $7.72 \pm 2.16 \mathrm{~mL}$ in group $0.5 \%$, while stomach volume values were $14.61 \pm 3.74 \mathrm{~mL}$ and $16.01 \pm 5.64 \mathrm{~mL}$ in group $2 \%$ and group $6 \%$, respectively. According to the information in the literature, as in other animals, stomach is the most important organ controlling the appetite in fish. Therefore, feed consumption occurs relative to the vacancy in the stomach. The time required for emptying the stomachs of the fish varies depending on water temperature, fish size, and the amount and quality of feed. In addition, it is associated with the gastric emptying phase, stomach stress rate, the surface area of the stomach, and the surface area of the consumed feed (Korkut, 2013). As a result of the study, it was demonstrated that the increase in the stomach volume of the fish was related to the amount of ingested feed and the size of the fish.

\subsection{Meat Composition}

Proximate analysis results of randomly sampled fish meat from the groups and their comparisons were given in the Table 2.

Table 2. The results of meat composition analysis according to groups $(\bar{X} \pm \mathrm{SH})$

\begin{tabular}{llll}
\hline & \multicolumn{3}{c}{ Experimental groups } \\
\cline { 2 - 4 } & I $(0.5 \%)$ & II $(2 \%)$ & III $(6 \%)$ \\
\hline Crude Protein (\%) & $17.48 \pm 1.09^{\mathrm{a}}$ & $19.00 \pm 0.90^{\mathrm{bc}}$ & $20.15 \pm 1.17^{\mathrm{c}}$ \\
Crude Oil (\%) & $2.74 \pm 0.70^{\mathrm{a}}$ & $3.47 \pm 0.99^{\mathrm{ab}}$ & $4.35 \pm 1.08^{\mathrm{b}}$ \\
Crude Ash (\%) & $1.34 \pm 0.15^{\mathrm{a}}$ & $1.37 \pm 0.11^{\mathrm{a}}$ & $1.39 \pm 0.10^{\mathrm{a}}$ \\
Dry Matter (\%) & $22.56 \pm 0.29^{\mathrm{a}}$ & $23.85 \pm 0.53^{\mathrm{ab}}$ & $25.93 \pm 1.39^{\mathrm{b}}$ \\
\hline
\end{tabular}

Note. Values in the same row with no common superscripts are significantly different $(\mathrm{P}<0.05)$.

In fish with different feeding ratio applications, crude protein analysis results were significantly different between groups I-II and I-III $(\mathrm{P}<0.05)$. The lowest crude fat ratio was determined in group I. That was followed by group II and III, respectively. According to the analysis results, the difference between the groups I - III was not statistically significant $(\mathrm{P}<0.05)$. At the and end of the experiment, by making use of the results of chemical analysis on the fish, the levels of crude protein, and crude fat fish meat were determined. Meat composition results obtained from all groups were lower than those obtained by Bureau et al. (2006) in their study on different feeding levels on rainbow trout, whereas their crude fat values were similar to those in group I and 
higher than those of the other groups. Crude fat values reported by Keskin and Erdem (2005) in rainbow trout were higher than those obtained in the present study, whereas crude protein values were similar.

It was determined in this study that different feeding ratios had significant effects on the growth, feed conversion, and visceral index ratios in addition to stomach volumes. In addition, the results obtained in this study were similar to those obtained in the previous studies.

\section{Conclusions}

The aim of this study was to reveal the effects of high density feeding rates on growth and stomach volumes in rainbow trout (Oncorhynchus mykiss).

At the end of the study, three different feeding ratios were positively affected the stomach volumes, and thus the visceral index values, showing that the stomach and internal organs of the fish fed with low feeding ratios had a proportionally lower mass. From that point of view, consumers clearly would benefit in the case of preferring fish produced with low feeding ratios. Although a lower growth performance was obtained in terms of specific growth rate, condition, which is one of the most important indicators affecting the market value of other species, show that the consumers may prefer the low feeding group.

In this study, it was determined that different feeding ratios had statistically significant effects on the growth, feed conversion, and stomach volumes of the fish. Growth, specific growth rate, and condition factors increased with the changes in the feeding ratios in addition to an increase in stomach volume. The results obtained as a result of different feeding ratios will contribute to the sustainability of the sector. Feed cost is the most important expense in rainbow trout aquaculture. In addition, release of excess fecal waste and inedible food to the environment may have negative consequences to the aquatic ecosystem.

Further studies will be based on that the recovery duration of the overextension of the digestive system, the determination of fish welfare throughout this process, and the environmentaly interaction.

\section{Acknowledgements}

This study was supported by Recep Tayyip Erdoğan University Scientific Research Projects Unit. Project No. 2012.103.02.1, "Influence of Different Fodder Densities on Growth Performance and Stomach Volume in Rainbow Trout (Oncorhynchus mykiss Walbaum, 1792)".

\section{References}

Abidi, S. F., \& Khan, M. A. (2014). Evaluation of feeding rate based on growth, feed conversion, protein gain and carcass quality of fingerling Indian major carp, Catla catla (Hamilton). Aquaculture Research, 45, 439-447. https://doi.org/10.1111/j.1365-2109.2012.03245.x

Al Zahrani, A. W., Mohamed, A. H., Serrano Jr, A. E., \& Traifalgar, R. F. M. (2013). Effects of feeding rate and frequency on growth and feed utilization efficiency in the camouflage grouper (Epinephelus polyphekadion) fingerlings fed a commercial diet. European Journal of Experimental Biology, 3(1), 596-601.

AOAC (Association of Official Analytical Chemists). (2000). Official Methods of Analysis (19th ed.). AOAC, Arlington.

Bascinar, N., Gumrukcu, F., \& Okumus, I. (2008). A study on feeding strategy of young rainbow trout (Oncorhynchus mykiss Walbaum). Journal of Fisheries Sciences, 2(3), 224-232. https://doi.org/10.3153/ jfscom.mug.200706

Bircan, R. (1986). The effects of number of daily feeding and feed levels on growth rate and feed efficiency of the rainbow (Salmo gairdneri) intensively cultivated in an artesian waters of Erzurum region. Ondokuz Mayis University Agricultural Science, 1(1), 9-18.

Bureau, D. P., Hua, K., \& Cho, C. Y. (2006). Effect of feeding level on growth and nutrient deposition in rainbow trout (Oncorhynchus mykiss, Walbaum) growing from 150 to 600g. Aquaculture Research, 37, 1090-1098. https://doi.org/10.1111/j.1365-2109.2006.01532.x

De Silva, S. S., \& Anderson, T. A. (1995). Fish Nutrition in Aquaculture (p. 319). Chapman and Hall Aquaculture, London,

Guzel, S., \& Arvas, A. (2011). Effects of different feeding strategies on the growth of young rainbow trout (Oncorhynchus mykiss). African Journal of Biotechnology, 10(25), 5048-5052. https://doi.org/10.5897/ AJB11.271

Horn, M. H. (1998). Feeding and Digestion. The Physiology of Fishes (pp. 43-64). New York. 
Jobling, M., Coves. D., Damsgard, B., Kristiansen, H. R., Koskela, J., Petursdottir, T. E., ... Gudmundsson, O. (2001). Food Intake in Fish, Techniques for Measuring Feed Intake (pp. 49-87). Blackwell Science, Oxford, UK.

Karabulut, H. A., \& Kurtoglu, I. Z. (2017). The Effect of Red Pepper to Add into Commercial Trout Feed on Growth Performance and Meat Quality of Rainbow Trout (Oncorhynchus mykiss). Fresenius Environmental Bulletin, 26(12/2017), 7473-7477.

Karabulut, H. A., \& Yandi, I. (2011). A mercury displacement method to measure fish feed density. Journal of Animal and Veterinary Advances, 10(12), 1516-1522. https://doi.org/10.3923/javaa.2011.1516.1522

Karatas, M. (2005). Fisheries Biology and Population Dynamics (pp. 357-375). Nobel Publications, Ankara, Turkey.

Keskin, E., \& Erdem, M. (2005). The effect on fish growth of using extruded feed at different ratio on the culture of rainbow trout (Oncorhynchus mykiss). Suleyman Demirel University Egirdir Journal of Fisheries, 1(1), 49-57.

Korkut, A. Y. (2013). The Importance of Fish Feed. Monthly Journal of Fisheries Water World, Jan.-Feb., 30-31.

Kuyumcu, N. (2001). The effect of different feeding on gaining weight and feed conversion ratio in rainbow trout (M.S. Thesis, Osmangazi University, Eskisehir, Turkey).

López, V. G., García Sisquella, I., \& Castelló-Orvay, F. (2002). Effect of daily food intake rate and different artificial feeds on the growth and feeding parameters of channel catfish Ictalurus punctatus. Revista de Investigaciones Marinas, 23(2), 149-153.

Marimuthu, K., Umah, R., Muralikrishnan, S., Xavier, R., \& Kathiresan, S. (2011). Effect of different feed application rate on growth, survival and cannibalism of African catfish, Clarias gariepinus fingerlings. Emirates Journal of Food and Agriculture, 23(4), 330-337.

Morales, A. E., Gardenete, G., Higuera, M., \& Sanz, A. (1994). Effects of Dietary Protein Source on Growth, Feed Conversation and Energy Utilization in Rainbow Trout, (Oncorhynchus mykiss). Aquaculture, 124, 117-126. https://doi.org/10.1016/0044-8486(94)90367-0

Ogata, H. Y., \& Shearer, K. D. (2000). Influence of dietary fat and adiposity on feed intake of juvenile red sea bream Pagrus major. Aquaculture, 189(3-4), 237-249. https://doi.org/10.1016/S0044-8486(00)00374-4

Ozdemir, A., Korkut, A. Y., Yuksel, T., \& Imam, H. (2002). Digestibility of some commercial fish feeds in the feeding of sea bass (Dicentrarchus labrax, Linnaeus 1758). Ege Journal of Fisheries and Aquatic Sciences, 19(1-2), 69-76.

Pereira, T. G., \& Oliva-Teles, A. (2003). Evaluation of corn gluten meal as a protein source in diets for gilthead sea bream (Sparus aurata L.) juveniles. Aquaculture Research, 34, 1111-1117. https://doi.org/10.1046/ j.1365-2109.2003.00909.x

Piper, R. G., McElwain, L. B., Orme, L. F., McCraden, J. P., Fowler, L. G., \& Leonard, J. R. (1983). Fish Hatchery Management (p. 517). U.S. Fish and Wildlife Service, Washington D.C.

Pirhonen, J., \& Forsman, L. (1998). Effect of prolonged feed restriction on size variation, feed consumption, body composition, growth and smolting of brown trout, Salmo trutta. Aquaculture, 160, $203-217$. https://doi.org/10.1016/S0044-8486(98)00215-4

Sahin, T. (1994). Optimal stocking density and daily feeding rate of rainbow trout (Oncorhynchus mykiss) in sea cages (PhD Thesis, Karadeniz Technical University, Trabzon, Turkey).

Segato, S., Bertotto, D., Fasolato, L., Francescon, A., Barbaro, A., \& Corato, A. (2006). Effect of triploid on feed efficiency, morphometric indexes and chemical composition of shi drum (Umbrina cirrosa L.). Aquaculture Research, 37, 71-77. https://doi.org/10.1111/j.1365-2109.2005.01398.x

Storebakken, T., Austreng, E., \& Steenberg, K. (1981). A method for determination of feed intake in salmonids using radioactive isotopes. Aquaculture, 24, 133-142. https://doi.org/10.1016/0044-8486(81)90050-8

Tarim, S., \& Akyurt, I. (1992). A study on the determination of optimum feeding level in rainbow trout (Salmo gairdneri R.). Ege Universty Journal of Fisheries, 9(33-36), 155-169.

Ustaoglu, S. (1996). The effects of different feeding levels on development and feed evaluation of rainbow trout (Oncorhynchus mykiss) growing in net cages in Black Sea (Sinop) (M.S. Thesis, Ondokuz Mayis University, Sinop, Turkey). 
Ustaoglu, S., \& Bircan, R. (1998). Tthe effects of different feeding rates on growth and feed conversion of rainbow trout (Oncorhynchus mykiss) reared in sea cages in Black Sea (Sinop). Turkish Journal of Veterinary and Animal Sicences, 22, 285-291.

\section{Copyrights}

Copyright for this article is retained by the author(s), with first publication rights granted to the journal.

This is an open-access article distributed under the terms and conditions of the Creative Commons Attribution license (http://creativecommons.org/licenses/by/4.0/). 